\title{
ICTs in Latin America: An overview
}

\author{
Rodrigo Santos \\ Dep.Ingeniería Eléctrica y de Computadoras - UNS \\ Instituto de Investigaciones en Ingeniería Eléctrica - CONICET \\ Avda. Alem 1253, 8000, Bahía Blanca, Argentina \\ Email: ierms@criba.edu.ar
}

April 25, 2009

\begin{abstract}
In this paper, the state-of-the-art on the field of Information and Communications Technologies (ICTs) in Latin America is presented. Its main contribution consists in the localization of common objectives for the majority of the countries in the region. Although the countries are very heterogeneous from the cultural and geographical perspectives, there are many common factors that can be exploited in order to develop their economies. At first sight, Brazil or Mexico with their huge populations and big economies are giants compared to other countries like Bolivia or Costa Rica. However there are many common problems in all of them that can be addressed with a common strategy. An important question that this presentation tries to answer is the ICT profile of Latin America: consumer or producer. Data from the World Bank on ICT infrastructure and from the academic sector on the actual situation of the R\&D activities in the region are analyzed to answer this question.
\end{abstract}

\section{Introduction}

In the last decade and specially in the last five years, there has been an increasing interest in all the governments of the regions to promote the ICTs. In this way the scientific community has the possibility to access new forms of economic aids to develop projects in this area. Some of these forms include the association with companies of the area to advance in the new technologies. The amount of funds available to these projects varies among the different countries and the economical capacity of them.

Almost all the countries have created a special official Secretary to lead the politics in this field. However the real investment and attention paid to the new technologies have not reached the same level in all these countries producing important asymmetries within the region. Most of these asymmetries are linked to the different economic capacities, the real interest of the governments in the development of these technologies and the restrictions imposed by their high external debt.

This paper is based on a presentation made at the 19th IFIP World Computer Congress that was held in Santiago, Chile, in a Workshop organized by Technical Committee 3 about IT Practitioners, in 2006. Since then some data has been modified and new programs are in development in the region. An updated vision of the ICTs in Latin America is then presented. 
The rest of the paper is organized in the following way: in Section 2, the general approach followed by all the countries is described; in Section 4, a short summary of the particular actions taken in the different countries is made; in Section 3 some statistics about the ICTs and their practitioners in Latin America are presented; in Section 5, some of the common initiatives that involve the countries of the region at both academic and governmental levels are presented; and finally, in Section 6, conclusions are drawn.

\section{Common guidelines in Latin America}

In general, all the countries have followed the same strategy with the ICTs. They have created a special organism to lead the development in this area and they have explicitly stated a set of lines of actions. The main objective of these programs is to integrate, coordinate and support actions for the utilization of ICTs in such a way that all the citizens of the country can be included in the new society contributing to the creation of a new competitive economy and labor market.

In these programs, the government, the private sector and the whole society are integrated in the following lines of actions: 1) Promotion of the national industry to be competitive. 2) General access to technology services and education. 3) Lifelong learning and introduction of ICTs in the curricula. 4) Recreation of the national identity through the support to the main areas that contribute to it. 5) Development and support of e-government, e-health and e-commerce 6) Promotion of projects of R\&D on ICTs at the universities. 7) Creation of a new infrastructure to connect the private networks with the public and academic ones. 8) Detection of the principal technologies that can lead the development of the industry and the economy of the countries.

Although all the countries share the same core ideas, there are differences in the implementations and the real impact of these policies on the development of the ICTs. In many cases the programs are not part of a national policy but the result of individual efforts. Once the person in charge is out of the government, the program related to him is not financed any more and forgotten. This is a big problem when searching for information through the Internet. In many cases, the web pages related to the programs have not been updated in years.

The development of ICTs requires the participation of IT professionals. The main problem in LA is the lack of professionals in the area. Although it is not a real measure of the amount of IT practitioners, the number of postgraduate students and professionals with a Master or PhD. degree gives an indication of the situation. Also the participation in scientific conferences and the number of original research published in indexed journals can give a feeling of the importance of the area in the region.

ICTs is an area sensible to the expertise of those guiding its development. The investment of the public and private sectors on the scientific sector related to the Informatics, Electronics and Communications (the three basic sciences over which the ICTs are based) is not enough. Even the education at the bachelor degree has serious problems both on infrastructure and financial items. As mentioned above, although there are important asymmetries among the countries it is possible to say that the average investment in this area measured per inhabitant or as percentage of the GDI is not enough for the creation of a critical mass of professionals. 


\subsection{Common statements}

In September 2006, in Punta del Este, Uruguay, the iberoamerican nations (Spain, Portugal and Latin America) met and produced an important document with the general lines of actions to be taken in the development of ICT as a tool for the growth of the nations [9]. In the document, 6 areas are described as the basic ones to work upon.

\subsubsection{Economic Gap}

ICTs can contribute to the reduction of the economic gap if certain conditions are met.

- Reduce or even eliminate the connectivity barriers by facilitating the access to everyone.

- Educate people in the use of ICTs incorporating them to the information society by stimulation the use of these technologies.

- Special incentives to develop contents in the natural language and simple applications.

\subsubsection{Geographic gap}

This point is of fundamental interest in the region. It is absolutely necessary to provide access to data and voice services even in the more remote rural areas. The problem also exists in urban areas where there are important populations without the minimum services like (electricity, water, etc.) and of course access to the data and voice telecommunication network. Without this, the geographical gap will not be closed. In this sense, the collaboration between the public and private sectors is of major importance.

\subsubsection{Education gap}

The education gap is not closing. While a part of the population is receiving the latest trends in technology, a great majority is every day a bit further away. The problem requires immediate action as the difference is growing. The first steps should be given in the training of teachers and professors in the use of ICTs as teaching practices. The effort should be made by both private and public sectors.

\subsubsection{Health gap}

The situation in health care is similar to the one in education. The introduction of ICTs is necessary in the management of the health care and in the implementation of solutions like telemedicine for rural areas where it is difficult to get together the patient and the physician.

\subsubsection{Economic growth}

The inversion in ICTs is fundamental for a long term economic growth. A good public policy can stimulate the inversion and produce quicker results for example in the area of e-government, e-learning and e-health. Outsourcing is a new way in which local companies can get involve in international projects selling products and services. 


\subsubsection{E-government}

This is a very important area because it improves the access to the public information and the transparency. All countries agree on the importance of developing new tools that speed up the administrative tramits. The alliance between the public and private sectors is fundamental for the development of the applications.

\section{ICTs in Latin America}

In this section, some statistics about the use and the number of IT practitioners in Latin America will be given. It is quite difficult to obtain this information and much more difficult to extract general conclusions for all the region. In fact, most of the data are outdated (2 years old, from 2006) and can only give an indication of the situation. What is important to find out is if LA has a consumer or producer approach to ICTs. Obviously, it is more significant to have a producer profile because it represents a true opportunity for the social and economical growth of the region.

A producer profile is stated as that of a country with an important participation in the Gross Domestic Income of the ICT technology industry, mainly electronics and software. That is a country where the technology is developed whether it is by designing electronic components that will be used in ICT devices (microprocessors, phones, I/O devices, etc) or by designing and producing the necessary software to make the electronics functional. A consumer profile instead, is stated as that of a country that uses the technology, it can even achieved a high level of penetration of it in the population, but it is not produced. In more simple terms, a country may import cars and they can be used by an important number of persons. They know how to drive the car. It is a consumer approach to cars. On the other side, there are countries that actually design and produce the cars. That is a producer profile.

To perform the analysis, two distinct approaches can be followed. In the first one, the number of Internet connections both dial-up and broadband, the number of cyber-cafes, the number of telephone lines and cell phones, the number of Cable TV connections, etc., can be counted and statistics per inhabitant, region, social class, etc. can be obtained. In the second approach, which is much more indirect, the scientific research and production in the area of ICTs can be studied and conclusions drawn from there. There is no doubt that if there is no scientific research in ICTs then the activity of ICTs will be reduced mostly to a consumer profile.

\subsection{ICTs in numbers in Latin America}

The World Bank produces information about the development of ICTs across the world [14]. Latin American countries are grouped in two big classes. The first corresponds to the countries with GNI per capita in the upper middle income group (i.e.: Argentina, Chile, Costa Rica), the second corresponds to the lower middle income group (Bolivia, Brazil, Ecuador). However this difference is not significant for the ICTs since most of the countries have similar accomplishments in this subject. Table 1 describes the situation in Latin America for the year 2005. For comparative purposes the situation for the Upper and Lower Middle Income countries' groups is included.

The situation in LA is not completely bad but there is still a long way to cut down the digital gap that exists with the developed countries. The main problems are in the level of adult literacy 
and percentage of primary, secondary and tertiary school enrollment. It is significant lower also the number of Personal Computers per 1,000 inhabitants and the amount of broadband subscribers. The expenditure as a percentage of the GDP is almost 2 points lower than in developed countries and there is little information on the number of schools connected to Internet.

\subsection{Academic activity}

The academic activity as a way to measure the ICT activity of Latin America has been addressed in [29]. In their study, they have found that the countries with older doctoral programs concentrate the majority of the activity. The analysis was done up to 1998. Since that year there has been an important increment of the number of researchers in ICTs in many countries but particularly in Argentina where many financial mechanisms to incentivate the area has been done. In Table 2 the number of PhDs working on subjects related to ICTs is presented. However, the information corresponds to 1998 and since then the community has markedly grown. For example, in 2004, in Argentina there are more than 80 PhDs. In 1998, the PhD programs on Computer Science of Argentina were just starting to show some results. Now, they have more than 10 years and are working regularly. The same situation arises in other countries like Colombia, where there are now $100 \mathrm{PhDs}$ working and many interesting projects like Parque Soft [22] under development. This reflects almost a duplication of the activity. In Uruguay for example, there are Master programs working very well and an important growth in research. The same thing happens in Paraguay were there are $6 \mathrm{PhDs}$ doing research and guiding the Master program. A new PhD program has been started in Paraguay during 2007. Unfortunately, is very difficult to collect detailed information about the real situation in Latin America.

In Chile for example, there is a research Center created by the research division of Yahoo and the Universidad de Chile (Web Research Center) [27]. This joint effort is the only research Center of Yahoo outside the United States apart from the one in Barcelona.

An interesting parameter is the number of researchers per inhabitant. Considering that approach, the situation is rather bad. Even if the total number of PhDs in 1998 is duplicated, and all the researchers working outside the region are considered to work in Latin America, the average ratio will be 8 researchers per million inhabitants with Costa Rica with 15 on one end and Peru with little more than 2 on the other end.

The basic problem for the region is the financial support for the graduate students. With scholarships that round U\$S 600 the number of students that continue their education with Master or Doctoral programs is very low. The graduate studies are not economically attractive. In many cases, students start working at the private sector of the economy before taking their degrees. Besides, there are little expectations, after the $\mathrm{PhD}$ degree is obtained, on the industrial sector. As can be seen in Table 2 the inversion of Industries in high qualified human resources is very low. Less than $10 \%$ of the PhDs have a place on the private sector. This fact shows a big problem present in the region that is the lack of inversion of the private sector on research and development. As the last component to this delicate situation, the brain-drain problem complicates the situation of some of the countries like Argentina, where the number of $\mathrm{PhD}$ researchers, as can be seen in Table 2, outside the country is equivalent to the number working in the country. 
Table 1: Latin American ICT indices. Source [14]

\begin{tabular}{|c|c|c|c|c|}
\hline & \multicolumn{4}{|c|}{ Region-Income group } \\
\hline & $\begin{array}{l}\text { Latin America \& } \\
\text { Caribeean }\end{array}$ & High & $\begin{array}{l}\text { Upper- } \\
\text { middle }\end{array}$ & $\begin{array}{l}\text { Lower- } \\
\text { middle }\end{array}$ \\
\hline \multicolumn{5}{|l|}{ Economic and social context } \\
\hline Population, total (millions) & 551 & 1,011 & 600 & 2,475 \\
\hline Urban population ( $\%$ of total population) & 77 & 78 & 72 & 50 \\
\hline Poverty ( $\%$ of population below US\$ 1 per day) & 8.6 & - & - & - \\
\hline GNI per capita & 4,045 & 35,264 & 5,634 & 1,923 \\
\hline GDP growth, 1995-2000 and 2000-5 & 2.3 & 2.2 & 3.5 & 6.3 \\
\hline Adult literacy rate (\% ages 15 and over) & 90 & 99 & 94 & 89 \\
\hline $\begin{array}{l}\text { Primary, secondary and tertiary school enrollment (\% } \\
\text { gross) }\end{array}$ & 80 & 92 & 79 & 71 \\
\hline Government priorization of ICT (scale 1-7) & 3.7 & 5.1 & 4.1 & 3.7 \\
\hline \multicolumn{5}{|l|}{ Access } \\
\hline Telephone main lines (per 1,000 people) & 177 & 503 & 230 & 205 \\
\hline International voice traffic (minutes per person) & - & 171 & 46 & 14 \\
\hline Mobile subscribers (per 1,000 people) & 324 & 835 & 671 & 306 \\
\hline Population covered by mobile telephony $(\%)$ & 90 & 99 & 84 & 76 \\
\hline Internet users (per 1,000 people) & 156 & 527 & 196 & 95 \\
\hline Personal computers (per 1,000 people) & 88 & 579 & 113 & 45 \\
\hline Households with television (\%) & 91 & 97 & 91 & 84 \\
\hline \multicolumn{5}{|l|}{ Quality } \\
\hline Telephone faults (per 100 main lines per year) & - & 5.8 & 20.3 & 25.0 \\
\hline Broadband subscribers (per 1,000 people) & 16.5 & 163.2 & 21.0 & 23.1 \\
\hline International Internet bandwidth (bits per person) & 161 & 4,537 & 218 & 116 \\
\hline \multicolumn{5}{|l|}{ Affordability } \\
\hline Price basket for fixed line (US\$ per month, residential) & 10.0 & 27.6 & 12.1 & 8.5 \\
\hline Price basket for mobile (US\$ per month) & 9.4 & 17.8 & 9.5 & 10.2 \\
\hline Price basket for Internet (US\$ per month, 2006) & 25. & 19.9 & 17.0 & 16.8 \\
\hline Price of call to United States (US\$ per 3 minutes) & 1.80 & 0.76 & 1.06 & 2.08 \\
\hline \multicolumn{5}{|l|}{ Institutional efficiency and sustainability } \\
\hline Total telecommunications revenue ( $\%$ of GDP) & 4.3 & 4.5 & 3.6 & 1.9 \\
\hline Total telephone subscribers per employee & 390 & 486 & 583 & 444 \\
\hline Total telecommunications investment ( $\%$ of revenue) & - & 15.1 & 24.3 & 19.2 \\
\hline \multicolumn{5}{|l|}{ ICT applications } \\
\hline ICT expenditure ( $\%$ of GDP) & 5.9 & 7.1 & 5.2 & 5.5 \\
\hline E-government readiness index (scale $0-1$ ) & 0.48 & 0.7 & 0.54 & 0.38 \\
\hline Secure Internet servers (per 1 million people) & 12.0 & 311.4 & 16.9 & 2.3 \\
\hline Schools connected to the Internet $(\%)$ & - & 99 & 60 & - \\
\hline
\end{tabular}


Table 2: Latin American Researches. Source [29]

\begin{tabular}{|l|llll|}
\hline Country & Universities & Industry & Abroad & Total \\
Argentina & 55 & 5 & 40 & 100 \\
Brazil & 1080 & 100 & 20 & 1200 \\
Chile & 65 & 15 & 20 & 100 \\
Colombia & 40 & 5 & 15 & 60 \\
Costa Rica & 20 & 2 & 8 & 30 \\
Cuba & 18 & 2 & 10 & 30 \\
Mexico & 470 & 30 & 100 & 600 \\
Peru & 20 & - & 10 & 30 \\
Uruguay & 15 & 5 & 15 & 35 \\
Venezuela & 40 & 5 & 15 & 60 \\
Others & 10 & 10 & 2 & 22 \\
\hline Total & 1833 & 169 & 263 & 2265 \\
\hline
\end{tabular}

\section{Description of the actions taken by the different countries}

In this section, the activities followed by the some countries from Latin America are presented. In general they proposed and follow the same lines of action. The information has been obtained through the Internet and in many cases is not updated. In fact, there are cases in which the program is announced but the web page has not been updated in the last two years or it is not available anymore. In [21] there is a repository for all Latin Americans countries that is quite useful to complete the general view on this subject.

\subsection{Argentina}

In Argentina, an important effort to introduce the ICTs as a national project, has been made. The different governments in the last decade have contributed to the development of the ICTs but unfortunately there has been little continuity in the process. In fact, there are programs that are still in course but that have no financial support anymore. The general lines in the area are oriented to provide universal access to the ICTs with the priority on the people with less resources. The projects include programs for e-government, e-health, e-learning and e-commerce. There are financial aids for ICT companies to develop new products and services. The academic sector has received and is accessing new financial support for the $R \& D$ of new technologies in the area. In particular, the government is very interested in the use of sensor networks, identification and traceability of the products like beef, soya, corn, grain, etc., which are part of the exportable products. Argentina is the only country in Latin America that has produced a national law that regulates and promotes the software industry giving special tax incentives to those involved in R\&D and that export their products. 


\subsection{Bolivia}

The main objective of the program Estrategia Boliviana de Tecnologías de la Información y la Comunicación para el Desarrollo is the integration of the ICTs to the developing process of the human resources with special interest in the rural population and those with lowest incomes [11]. The program has many lines of actions to achieve the general objective. These lines are:

- To develop processes in which there are participation and interchange of information and ideas to capacitate the individuals.

- To achieve an education level of the population that allows the use and the interchange of information and ideas through the ICTs.

- To establish the technical and material conditions for the access, generation, transmission and reception of the information.

- To have a proper set of laws and regulations for the ICTs that allow the creation of infrastructure and capacities for the use of these technologies.

- To develop the mechanisms for the administration and assignment of public and private resources in a sustainability way.

- To publish and share the scientific, technological and cultural knowledge.

- To impulse the growth and development of the traditional economy (agricultural, forestry, mining and tourism) through the use of ICTs.

- To achieve a complete informatization of the State in such a way that actions of government have transparency and the e-government can be reached.

- To impulse the use of ICTs to improve the competitivity of the industrial sector and its insertion in the global market and also to create the opportunities for the development of national ICTs industries.

- To introduce e-health as mechanism to improve the quality of life of the citizens.

\subsection{Brazil}

The main objective of the program for the Information Society is to integrate, coordinate and support actions for the utilization of ICTs in such a way that all the citizens of the country can be included in the new society contributing to the creation of a new competitive economy and labor market [31]. The program has the following lines of actions:

- Promotion of the national industry to be competitive and the expansion of the middle and small companies through the use of the e-commerce and the offer of new kind of services and education.

- Promotion of the general access to services and education for the citizens. 
- Support of the continuous education (lifelong learning) and of the introduction of ICTs in the curricula.

- Promotion of the main areas that contribute to strengthen the national identity.

- Promotion of forms of e-government, e-health and e-commerce

- Identification of the principal technologies for the national development of the industry and the economy and promotion of projects of R\&D on ICTs at the universities.

- Creation of a new infrastructure to connect the private networks with the public and academic ones.

\subsection{Chile}

The program in Chile is named Estrategia Digital [28]. It establishes a multilateral group that has the mission of contributing to the development of the country through the use of ICTs to increment the competitivity, the individual freedom, the equality of opportunities, the quality of life, the efficiency and the transparency of the public sector. At the same time it tries to enrich the cultural identity of the country and its aborigine population. The concept is that ICTs are instruments of the development. The program has six lines of action:

- Universal access to the new technologies.

- e-Learning and capacitation at all levels, shortening in this way the geographical distances.

- e-Government

- Digital development of the industries to participate in the global market and improve the productivity.

- Development of the ICTs industry in the country.

- Laws and regulations.

\subsection{Colombia}

In Colombia the program is named Agenda de Conectividad [1]. The general objective is to impulse the social and economical development of the country through the massive use of ICTs. Recently, the government has stated the fundamental lines of actions:

- The generation of the proper space for the access to the ICTs in order to improve the productivity and the competitivity of the companies with equal opportunities for the access to the information.

- To improve the infrastructure and the access to the ICTs to guarantee the inclusion in the information society of all the citizens but specially of those with less resources. 
- To promote the creation and acquisition of capacities for the development of basic abilities to use this important tool.

- To promote the use of ICTs in the companies as an instrument to insert the Colombian products in new markets.

- The use of these technologies to improve the work in the academic sector with special impact on the creation of a broadband network.

- To modernize the State in order to increment the transparency and efficiency of the acts of government.

- The generation of national and local contents in accordance to the interests and the necessities of the population.

- The promotion of the ICTs national industries.

\subsection{Costa Rica}

In Costa Rica, the ICTs are one of the strategic topics that the government has been working on in the last six years. The organ in charge is the Ministry of Science and Technology. In fact, Costa Rica has one of the highest percentage participation of its population in this area, at least at the basic level (telephony) in Center America. The main lines of actions of the program are [30]:

- e-Learning

- Advanced networks and the development of ICTs

- Internet 2

- Broadband Internet and the IP Project

- The Technological Alliance program for the use of computers-ACCESO

- CONATIC

- e-Government

- Program Communications without frontiers.

\subsection{Ecuador}

In Ecuador the program is in charge of the National Council for the Telecommunications. It is named Agenda Nacional de Conectividad and it coordinates the strategies, programs and projects that contribute to the development and diffusion of the ICTs in the areas of education, health, environment, commerce, industry, tourism, security and government [2]. The principal lines of the program are:

- Infrastructure for the universal access to the Information Society. 
- e-Learning.

- e-Health.

- e-Government.

- e-Commerce.

\subsection{Mexico}

In Mexico the program for the instrumentation of ICTs is named Sistema Nacional E-Mexico and is guided by the Federal Commission of Telecommunications [25]. The main objective is to provide the necessary conditions and infrastructure for the adoption of the ICTs as the natural way to interconnect the different actors of the society: people, companies, government. The program includes the development of services in education, health, science, economy, industry and technology and government. The objectives are:

- To include the whole society in the use of the new technologies.

- To interconnect all the citizens through a digital interactive network in such a way that everyone can access the information related to the education, the culture, the government, etc.

- To interconnect all the communities independently of the distance and the geographical or cultural difficulties.

- To have a good legal framework for the development of the new technologies that allow the use of the ICTs by everyone.

- To make the use of ICTs profitable from a social point of view.

- To integrate the public and private efforts to achieve a good penetration of these technologies in the society and the impulse for the local ICTs industry.

\subsection{Paraguay}

ICTs are guided by the National Comision of Telecommunications. There is not an specific program as is the case of the other countries [6]. However, the Comision is in charge of administering everything related to the communications including the digital ones. The penetration indices of ICTs in the country are very low and the greater impact is in the Capital District where the population with better education and economic level lives. There is, however, an important effort from the academic sector to change this situation and the existence of a postgraduate program on communications at the Universidad Nacional de Asunción is a major advance. Presently there are 6 PhDs and many MSc working in Paraguay. 


\subsection{Peru}

In Peru the organism in charge of the ICTs is the Comisión Multisectorial para el Desarrollo de la Sociedad de la Información (CODESI) [23]. It has divided the work in six basic areas: 1) Infrastructure for the development of the Information Society; 2) Development of the human resources; 3) Development and Application of ICTs in social programs; 4) Development and Applications of ICTs in the productive and the service sectors; 5) e-Government; and 6) World Meeting for the Information Society. The CODESI has established a matrix for the development of these areas that has the following objectives:

- To have the necessary infrastructure for the telecommunications in order to develop the Information Society.

- To promote the necessary capacitation for the access to the Information Society.

- To develop the social sector of the country guaranteeing the access to high quality social services, and at the same time promoting new forms of work, with special attention to the promotion of the scientific research and technological innovation.

- To give support to the productive and the service sectors for the developing and applications of ICTs.

- To bring together the State and its processes with the citizens and the companies world through the offer of high quality and transparent services using ICTs.

\subsection{Uruguay}

In Uruguay there is a program named Uruguay en Red [26]. The project has been under development for the last years and has achieved important objectives like the integration of schools to the Internet, the capacitation of teachers and professors in the use of ICTs for teaching, etc. The program has many projects that have evolved with different performances but in general lines have contributed to the expansion of these technologies among the different communities, reaching the rural areas outside the capital district. There is also a mixed initiative from the academic and industrial sectors named Centro académico-industrial para Investigación y Desarrollo en Tecnologías de Información (CAITI). This project provides incentives to the software industry providing the basis for the development of new companies that work alone or together with foreign ones. The software industry in this country is very important and counts with an important academic support from the Universidad de la República. The country participates with Brazil and Argentina in many projects related to ICTs. [19]

\subsection{Venezuela}

The organism in charge of the program is Centro Nacional de Tecnología de Información. Its main

objective is the promotion of the ICTs in the development of the country with special interest in education, health, environment, public administration and commerce. The basic guidelines are:

- To promote the R\&D and the technological transfer in the ICTs. 
- To develop human resources and investments in the ICTs.

- To modernize the State through the intensive use of the ICTs to improve the quality of the services provided.

- To promote the use of ICTs in the productive sector to improve the productivity and the competitivity.

- To promote the use of ICTs in a democratic way to achieve a universal access to the Information Society.

\section{Common programs and activities}

The countries of the region have been working on common strategies to develop the ICTs. In the last meeting in Rio de Janeiro they have agreed over a set of actions to follow. The document has been published and can be consulted in [3]. Basically it specifies the common points expressed in section 2. There are many projects in the area that establish relations with European countries or the United Sates. Among the European countries, France, Germany, Spain, Italy and Great Britain are the most related to Latin America through special programs like the British Council or DAAD scholarships. There are also many Alfa programs in course that require the participation of Latin American countries and European ones. With the United States, there is a historical relation, stronger in the case of Mexico. The Fulbright scholarships have a big impact on the formation of human resources. In what follows, the most important initiative will be shortly described.

\section{$5.1 @$ lis}

@ lis (Alianza para la Sociedad de la Información entre América Latina y Europa) was born in 2001 as project from the European Community to reduce the digital gap between the continents and to the intern of Latin America. The project have had four basic directions of actions which were: education, health, government and social inclusion. In total more than 220 people were involved in @lis and the results are promising [16]. In fact, the projects have outperformed the expectations initially state and the programs have got an important impact in the region. Results on bridging the gaps in connectivity, health care, education, information, training, employment, collaboration, citizens-administration, have been important. In what follows some of the more important are mentioned. Integra, is a project, developed in Buenos Aires and La Pampa (Argentina) and in Valparaiso (Chile) which has provided $100 \%$ increment in the connectivity of the schools in La Pampa and 50\% in Valparaiso. For the case of Buenos Aires almost 400 schools between secondary and primary ones have been provided with a broadband connection [15]. Another important project developed to interconnect isolated rural areas by means of wireless connections like WiMax and radio has been developed in Costa Rica, Brazil, Colombia, Chile, Uruguay and Argentina [18]. The Silae experience has created 6 points with Internet access among the Amazon region [24]. The list of contributions is very long. However, it is important to remark that these projects have proved that it is possible to take the necessary connectivity even to isolate regions and provide with new tools for the development. The results extend in e-health with projects like eHas that has developed tools for health care training by means of telecommunications networks adapted to the rural areas. 
It was developed in Peru, Colombia and Cuba [10]. In Brazil, the HealthCareNetwork provides telemedicine services to those with difficult access to specialized hospitals [13]. Telemed is another project, implemented in Brazil and Colombia, to use ultrasonic exams by means of telemedicine. It helps in the fight of infectious tropical diseases such as malaria and tuberculosis and in the control of pregnancies [12]. Some projects were done to bridge the information gap, like Ciberanium [17] or Migrantes en linea [20]. For the educational gap, many projects work together like [15], or [4] that has provided tools for connecting rural areas to the education with impact in Argentina, Chile and Peru. The employment gap has been bridged also by many projects. Among them, Emplenet, [8], provides ICT training and information, counseling and insertion in the labor market. The collaboration gap has been bridged also through different projects like [18] and [24]. The @lis project has proved that the digital gap can be bridged in all their aspects if the governments, the private sector and the academic one cooperate.

\subsection{CLARA}

An important academic project in the region is CLARA (Consorcio Latinoamericano de Redes Avanzadas) [7]. It is a broadband network interconnecting academic institutions of Argentina, Bolivia, Brazil, Colombia, Cuba, Chile, Ecuador, El Salvador, Guatemala, Honduras, Mexico, Nicaragua, Panama, Paraguay, Peru, Uruguay and Venezuela. This, not only benefits the country itself, but gives the opportunity to be part of a global academic network since CLARA is connected to the European network GEANT through the project ALICE (Latin America Connected to Europe) [5] which has been supported in the general framework of the @lis project.

\section{Conclusions}

In this paper a general view of the ICTs in Latin America has been presented. The situation is neither bad nor good. There are many good things but many others to improve. There is a consumer approach at the moment that implies high employment at the service sector of the economy related to the communications (telephone main and mobile lines). However, the research activity in the area is poor with very little impact at world level. The number of PhD. graduates is not very high, the available postgraduate programs is not enough and the amount of money invested by governments for financing this kind of studies is low. All together produce an incipient activity but that is still far from transforming the region from an ICT consumer to an ICT producer. The numbers of ICTs are in accordance to the rest of the countries in the same economic group. However, if the true intention is to close the gap with the developed countries, more aggressive

policies should be taken. The situation can be improved if more financing is available to sustain projects related to ICTs and special incentives are given to the researchers working in the area.

\section{References}

[1] Agenda de conectividad. http://www.agenda.gov.co/.

[2] Agenda de conectividad. http://www.conatel.gov.ec/website/ conectividad/conectividad.php. 
[3] Agenda digital-documentos. servlet/aawscolver?2, ultimodoc, $, 1,0$.

http://www.agendadigital.cl/aws00/

[4] Alliance for the development of information technologies in the rural areas. http://www.alisonline.org /Projects /index_html /ADITAL.

[5] America latina interconectada con europa. http://www.alis-online.org/ Projects /index_html/ALICE.

[6] Comisión nacional de telecomunicaciones. http://www.conatel.gov.py/.

[7] Coperación latinoamericana de redes avanzadas. http://www.redclara.net/.

[8] Emplenet. http://www.alis-online.org /Projects /index_html /EMPLENET.

[9] Encuentro iberoamericano sobre los "objetivos del milenio de naciones unidas y las tecnologas de la informacin y comunicaciones (tic)". http://www.iadb.org/sds/doc/PuntaEst.pdf.

[10] Enlace hispanoamericano de salud. http://interno.ehas.org/proyectos / proyectos /ehas-lis.

[11] Etic: Estrategia boliviana de tecnologias de la informacion y la comunicacion para el desarrollo. http://www.etic.bo/Default/default.htm.

[12] Evidence based telemedicine for remote and rural underserved regions in la. http://www.alisonline.org /Projects /index_html /TELEMED.

[13] Health care network. http://www.healthcarenetwork.it/.

[14] Ict at glance. http://web.worldbank.org/WBSITE/EXTERNAL/ DATASTATISTICS/ 0,,contentMDK:20459133 menuPK: 1192714 pagePK:64133150 piPK:64133175 theSitePK:239419,00.html.

[15] Integra. http://www.integraproject.org.

[16] @lis. http://www.alis-online.org/.

[17] @lis-ciberanium, pedagogica settings for it literacy. http://www.alis-cibernarium.org.

[18] Local communities insertion network para américa latina. http://www.link-all.org.

[19] Memoria anual 2004 comit nacional para la sociedad de la informacin. uruguay. http://www.colombiadigital.net/informacion/docs/mempCom.uy.pdf.

[20] Migrantes en linea. http://interno.ehas.org/proyectos / proyectos / ehas-lis.

[21] Observatorio del desarrollo digital. http://www.colombiadigital.net/ observatorio/america.php.

[22] Parque soft. http://www.parquesoft.com. 
[23] Plan de desarrollo de la sociedad de la información en peru, la agenda digital preuana. http://www.peru.gob.pe/AgendaDigitalPeru/agendadigital.htm.

[24] Silae - servicios de iniciativa local para la amazonía ecuatoriana. http://www.silae.org.

[25] Sistema nacional e-mexico. http://www.emexico.gob.mx/wb2/eMex/ eMex_El_Sistema_Nacional_eMexico_un_Sistema_de_Par?page=1.

[26] Uruguay en red. http://www.presidencia.gub.uy/mem2000/info/CNSI.htm.

[27] Yahoo! research latin america. http://research.yahoo.com/location/ yahoo_research_latin_america.

[28] Agenda digital-plan de accion. http://www.agendadigital.cl/, 2004.

[29] R. Baeza-Yates and J. Pino. Computer science research in latin america. Technical report, Computer Science Department, Universidad de Chile, 2000.

[30] Ricardo Chacon. Politicas publicas de tics 2002-2006. http://www.micit.go.cr/.

[31] Gobierno de Brasil. Bases do programa brasilero para la sociedade da informacion. Technical report, Ministerio de Ciencia y Teconologia, 1999. 